\title{
Immunology Test
}

National Cancer Institute

\section{Source}

National Cancer Institute. Immunology Test. NCI Thesaurus. Code C16723.

Laboratory test involving interaction of antigens with specific antibodies. 